\begin{tabular}{|c|c|}
\hline Title & The Multiple Character of the Biochemical Mechanism of Freezing Resistance of Plant Cells \\
\hline Author(s) & Siminovitch, D.; Gfeller, F.; Rheaume, B. \\
\hline Citation & Cellular Injury and Resistance in Freezing Organisms: proceedings, 2, 93-117 \\
\hline Issue Date & 1967 \\
\hline Doc URL & http:/hdl.handle.net/2115/20411 \\
\hline Type & bulletin (article) \\
\hline Note & $\begin{array}{l}\text { International Conference on Low Temperature Science. I. Conference on Physics of Snow and Ice, II. Conference on } \\
\text { Cryobiology. (A ugust, 14 19, 1966, Sapporo, Japan) }\end{array}$ \\
\hline File Information & 1_p93-117.pdf \\
\hline
\end{tabular}

Instructions for use 


\title{
The Multiple Character of the Biochemical Mechanism of Freezing Resistance of Plant Cells*
}

\author{
D. Siminovitch, F. Gfeller and B. Rheaume \\ Plant Research Institute and Ottawa Research Station. \\ Canada Department of Agriculture, Ottawa, Canada
}

\begin{abstract}
Studies of the seasonal changes in quantity and metabolism of proteins, nucleic acids and carbohydrates of normal and starved (by double summer girdling or by summer isolation of islands of bark on the trunk) tissues of the living bark of the trunk of the black locust tree, Robinia pseudoacacia L. suggest that several mechanisms of freezing resistance which, under some conditions can be induced to operate independently, contribute to the total expression of freezing resistance in this tree. Some studies with the wheat plant also support this conclusion. The close correlation of rhythmic and abrupt autumn increases in soluble protein and ribonucleic acids with similar increases in freezing resistance suggest augmentation of total protoplasm which extends to the organelles, nuclei and possibly other critical structural components of the cell, is implicated in the primary mechanism of freezing resistance in the bark cells. This is supported by evidence of simultaneous limitation of net protoplasmic synthesis with freezing resistance in starved tissues. The possibility that seasonal rhythms in the tree and not low temperature per se are the environmental factors initiating and controlling these transformations in the protoplasm and hardiness of the bark cells is suggested. The function of the increase in ribonucleic acid components of the cell in this transformation seems to be largely a catalytic one. The development of partial but definite resistance in bark tissues so starved in summer that no increase in protein or nucleic acid occurs suggests the existence of a subsidiary mechanism of resistance which is not dependent on protoplasmic augmentation, but may operate in conjunction with it under normal conditions. Studies with these bark tissues and with wheat indicate that this mechanism is promoted by temperatures near or below the freezing point. The chemical changes involved are obscure but preliminary studies suggest these to be lipide transformations which may occur during the hardening of normal trees as well. The lack of correlation of soluble carbohydrates with freezing resistance under these and normal circumstances cannot be reconciled with a postulated role of soluble sugars in the frost hardening mechanism. Small but definite increases in freezing resistance which are observed to be closely associated with starch-sugar transformations must therefore be related to the removal of starch and not to the increase in soluble sugars. If restricted in this sense, starch-sugar transformation can be considered to be yet a third mechanism of freezing resistance. It is suggested therefore that the total expression of freezing resistance in locust tree and other plant cells involves the participation of all three mechanisms.
\end{abstract}

\section{Introduction}

The acquisition of freezing resistance in plants is due to a capacity to develop, under suitable conditioning, a tolerance to intercellular freezing. Intracellular ice formation may take place under rapid freezing conditions and is invariably lethal to both hardy and non-hardy cells but for the purpose of this study need not be given primary consideration. In plant tissues with small cells where the ratio of surface to volume is

* Contribution No. 545, Plant Research Institute, and No. 177, Ottawa Research Station. 
high as in the cells of tree barks, intracellular freezing is an uncommon event in nature in any case although the possible importance of this type of freezing damage has been stressed (Siminovitch and Scarth, 1938; Modlibowska and Rogers, 1955; Asahina, 1962; Sakai, 1963). It has also been shown that hardened tree cells are less prone to this type of freezing (Siminovitch and Scarth, 1938) so hardening must produce changes which resist the penetration of ice crystallization to the interior of the cell. Normal hardening off in plants and especially in trees, depends, however, largely on resistance to the effects of ice formation in the intercellular spaces.

At moderate freezing temperatures these effects are visibly dehydrative in character causing in non-resistant cells an irreversible coagulation of the protoplasmic membrane or of the protoplasm resulting ultimately in cell rupture during thawing. These effects of freezing and the positive correlation of frost resistance with resistance to dehydration have been well described and documented (Siminovitch and Levitt, 1941; Siminovitch and Briggs, $1953 \mathrm{a})$. Since it will be shown here that variations in resistance extend throughout the range of freezing temperature down to liquid nitrogen and thus below the temperatures where the major part of the water of the cell has been lost, differences in injury in this range of temperature cannot arise simply from differences in extent of mechanical contractions and expansions in freezing and thawing of a dehydrated, viscous or coagulated membrane but from more deeply seated changes in the macromolecules of the essential cell structures caused by removal of tightly bound water. Injury caused thereby may still be grossly manifested in cell rupture. There is little knowledge of the exact molecular processes or sites involved in this dehydration injury other than the suggestion that-SH groups of protein are involved (Levitt, 1962). Whatever these processes or sites may be, it is obvious, since a tree cell which cannot withstand $-10^{\circ} \mathrm{C}$ in summer can tolerate freezing at liquid nitrogen temperatures in winter, that remarkable chemical processes or transformations must be taking place in the protoplasm of these cells in autumn.

The present paper is a summary of recent chemical studies on the black locust tree which have attempted to resolve the nature of these processes and transformations. Because these studies are of a seasonal nature it is difficult to dissociate those processes which are purely seasonal phenomena in the tree from those which are pertinent to the processes involved in the mechanism of hardiness. There will also be brought to bear on the problem the results of some recent studies which have been made and are continuing to be made on winter wheat.

The studies on tree cells have been made primarily with the living bark of 10-20year-old trunks of the black locust tree Robinia pseudoacacia L. because extraction of protoplasmic constituents is readily achieved. The bark is also thick, affording a large supply of tissue for multiple sampling of the same trunk without injury to the tree, and containing an abundance of secondary phloem parenchyma the cells of which do not undergo visible growth or cell division during an annual cycle. The bulk of the analyses was performed on this phloem parenchyma after removal of the cambium and periderm layers. The seasonal chemical changes which will be related to hardiness are therefore uncomplicated by the effects of growth or cell division 


\section{The seasonal changes in frost hardiness}

Frost hardiness was determined by a new technique which measured freezing resistance at all freezing temperatures even down to liquid nitrogen (Siminovitch et al, 1964). The procedure was simply to thaw the plants or plant tissues and then to leach the liberated amino acids into water where they could then be measured by means of the Moore and Stein (1954) ninhydrin method. This procedure was really an extension of the method first introduced by Dexter et al. (1932) wherein the amount of salts released from injured cells after freezing and thawing was determined by conductivity methods. The intensity of the colour reaction of ninhydrin with amino acids and the high concentration of the free amino acids in the cell pool relative to that which was present in the non-living components of the tissue made this method a very sensitive one for appraising cell survival in freezing tests.

Fig. 1 shows the positive correlation of this method with vital staining obtained in a study of the changes occurring in the hardiness of the black locust tree from summer to winter (Siminovitch et al, 1964). In black locust tree cells the temperature which caused $50 \%$ release of amino amino acids was usually found to be lethal to the cells.

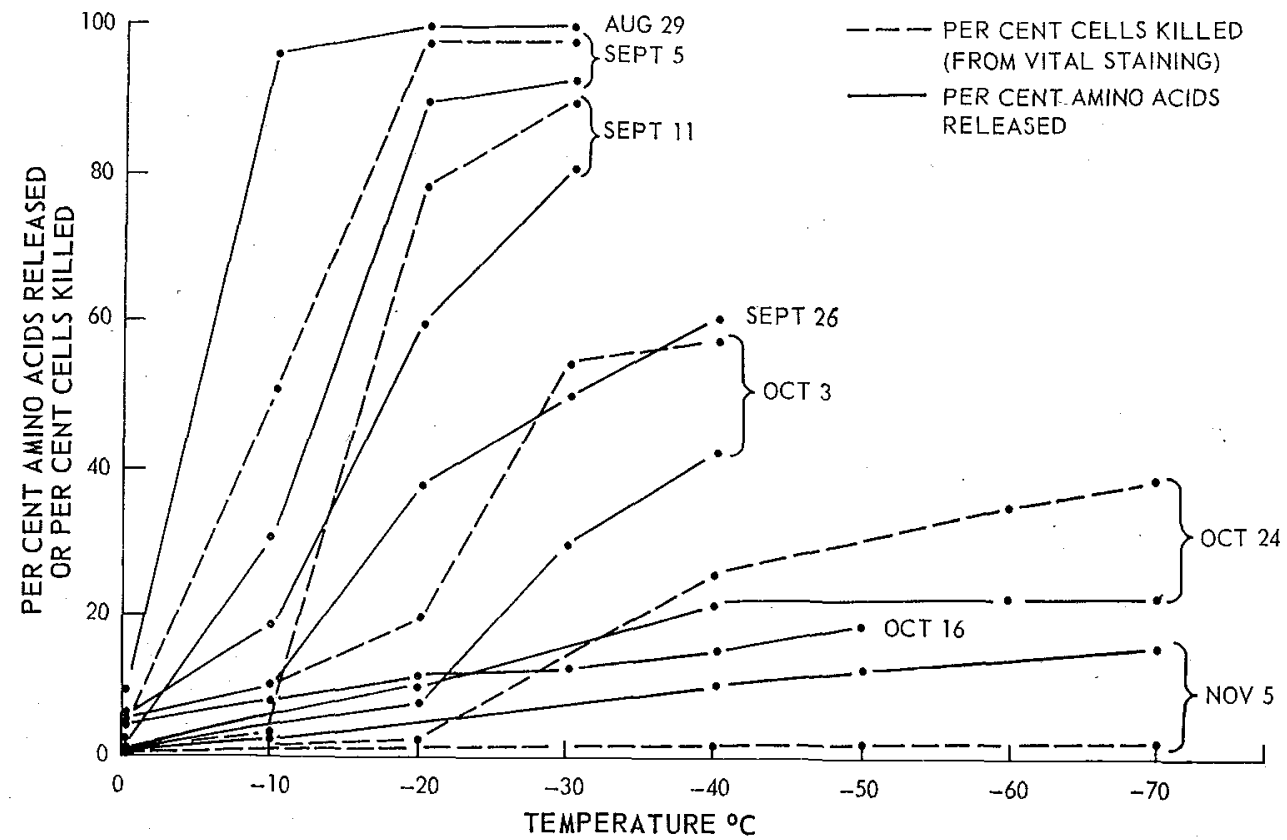

Fig. 1. Progress of frost hardening in the living bark of the black locust tree in the fall as determined by vital staining and amino acids released from tissue frozen to temperatures indicated. Amino acid release shown as precentage of total released by lethal freezing conditions (fast freeze at $-70^{\circ} \mathrm{C}$ ) and injury by percentage of cells not capable of taking up vital stain (Siminovitch et al., 1964)

On each date, samples of tissue were removed from the tree, wrapped in aluminum foil and exposed to different freezing temperatures in a test cabinet. They were then thawed rapidly or slowly and immersed in tap water for leaching. Amino acids in the leachates were determined with the ninhydrin method of Moore and Stein (1954) 


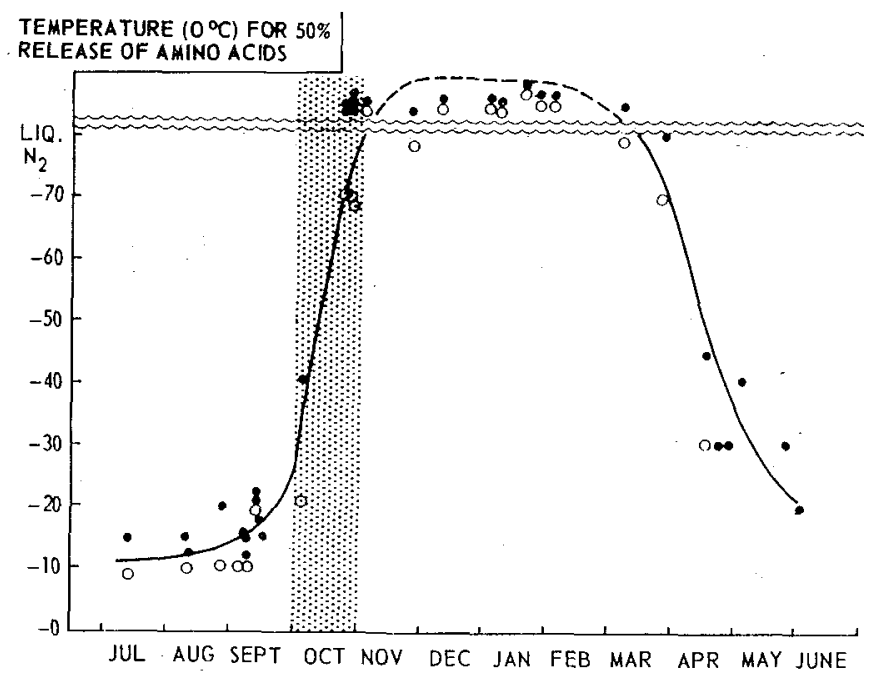

Fig. 2. Seasonal variations in the resistance of the living bark tissue to freezing injury measured by temperature required to produce release of $50 \%$ of the amino acids from the cell pool (Siminovitch et al., 1967). Results with fast thawing indicated in white circles and with slow thawing in black circle. Hardiness determined as in Fig. 1

From data like this obtained from tests performed throughout the year on tissues from the trunk of the same tree a graph was constructed in which the temperature which caused 50\% release of amino acids was plotted against the date of sampling. This graph is shown in Fig. 2. In some cases both slow thawing (black circles) and fast thawing (white circles) were used on the same tissue to better bring out the degree of sensitivity to freezing. Circles in Fig. 2 placed above the jagged pair of lines at liquid nitrogen temperatures denote that on the corresponding date of sampling not even liquid nitrogen followed by fast or slow thawing was effective enough to damage the cells beyond the point of recovery as indicated from the amount of amino acids released or by any other criteria of viability.

The amino acid release method using both slow and fast thawing permitted distinct gradations in hardiness to be established in tissues varying in degree of hardiness and must have therefore measured the stress in consequence of removal of water by freezing. Fig. 2 serves to emphasize the remarkable amplitude of change in resistance experienced by the bark tissues of the trunk of the black locust. Fig. 2 conveys, as earlier seasonal data on hardiness of these tissues (Siminovitch and Briggs, 1949, $1953 \mathrm{~b}$ ) did not convey, the abruptness of this change in the autumn. This change was so striking that in Fig. 2 as well as in Fig. 4, which will later depict the seasonal chemical changes, the period corresponding to this change is delineated on the graphs by a stippled region. The graph in Fig. 2 shows further that the drop in resistance in spring was more gradual than the rise in autumn but the change in resistance in spring could not be clearly discerned because of what appeared to be, as indicated below, masking effects of starch formation from sucrose. In autumn there were similar but converse effects caused by low temperature when starch changed to sugar but, for reasons which are as yet obscure, 
the effect on hardening as measured by the methods used was not considerable. Unquestionably, the sensitivity of the hardiness test could have been improved by scaling down the injury required to indicate freezing damage at any one temperature. However, when the lethal temperature for hardiness ascertained by the amino acid method was plotted against the date as in Fig. 2, the abruptness of the major hardiness change in the autumn in all black locust trees examined was unmistakable. The timing and sharpness of this transition was crucial to our understanding and interpretation of the seasonal chemical changes in black locust trees.

\section{Carbohydrates in relation to resistance}

Two principal types of chemical change which were greatly different in speed, timing and nature of the components involved and which had a bearing on hardiness characterized the seasonal chemical processes of the black locust. The seasonal variations in the carbohydrates consisting largely of starch, sucrose and to a lesser extent some reducing monosaccharides constituted the first type of change. The annual variations in these carbohydrates are shown in Fig. 3 (Siminovitch et al., 1953). The variations could best be described as beginning and proceeding with a rise in sucrose in early summer due to assimilation and translocation from the leaves. Then as radial and terminal growth slowed down or ceased entirely towards the end of the summer, use of carbohydrates in metabolism was diverted to use in storage and both sucrose and starch were increasingly accumulated with starch presumably being formed from excess sucrose. By October both of these carbohydrates were at a maximum. Then in late October, under the influence of low temperature, there was the familiar waning of starch although at this time there was not the expected corresponding increase in sucrose or other sugars to account for the amount of starch disappearing. This discrepancy had been reported

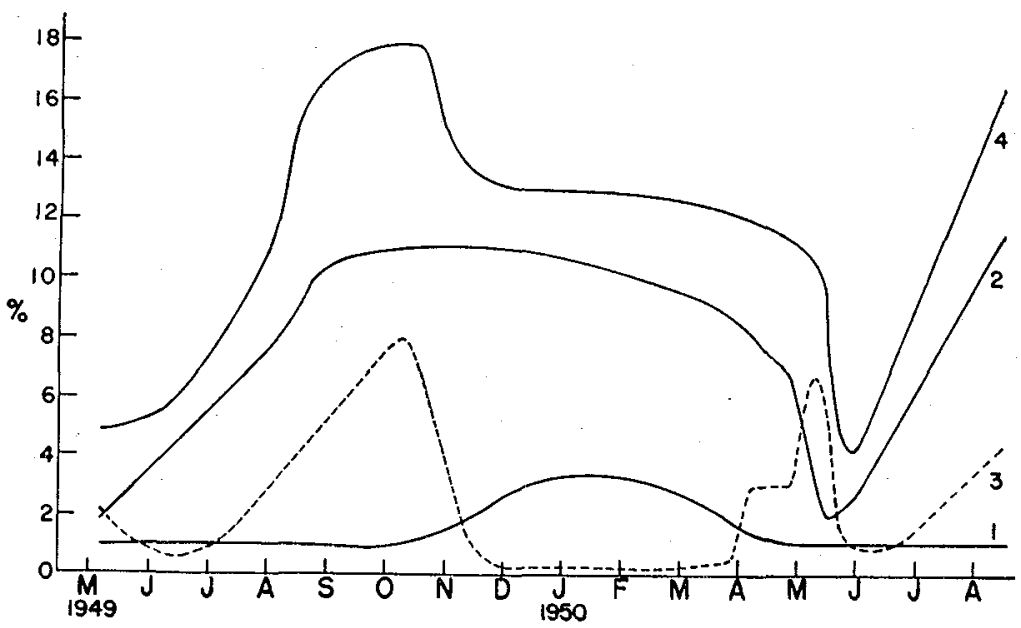

Fig. 3. Average seasonal variation as per cent of dry weight of tissue, in reducing sugars (curve 1), sucrose (curve 2), starch (curve 3), and total reserve carbohydrates (curve 4) in the living bark tissue of 12 Robinia trees during the period from May 1949 to August 1950. (Siminovitch, Wilson and Briggs, 1953) 
by others (Gibbs, 1940). The soluble sugars diminished somewhat through the winter but in spring, with the advent of higher temperature, there was a rapid and almost quantitative conversion of sucrose back to starch, the latter then being used preferentially as substrate for the initial flush of growth. Similar seasonal changes in carbohydrates occurring in other deciduous trees have been well described and have been a familiar pattern of seasonal and hardiness studies on these trees (Levitt, 1956; Kramer and Kozlowski, 1960).

The accumulation of a high concentration of carbohydrates and particularly of soluble sugars in autumn and the variations in resistance with reversible starch-sugar transformations induced by variations in temperature, with hardening and sugar formation from starch being favoured simultaneously at low temperatures, has long and popularly provided the basis for the chemical explanation of hardening particularly in view of the anti-freeze action of sugar. With the limited applicability of the anti-freeze hypothesis to the extremes of adaptation to freezing in tree cells, a postulated role for sugar in the protection against freezing injury was first abandoned and then revived on a number of fronts with some better theoretical and experimental support by Levitt, Sakai and others (Levitt, 1959; Parker, 1959; Sakai, 1962 b, 1966). This protection has been variously attributed to purely osmotic effects caused by natural or artificially induced increases in concentration of sugars after penetration into the cell (Levitt, 1957) or to effects on the surface membrane provided by sugar solutes which do not penetrate (Sakai, 1962 a ; Levitt, 1964).

The protective effect of sugars is considered by Heber (1959 a) to arise from the prevention by sugars of denaturation or coagulation of proteins by freezing. There is no question about the validity of these observations of effects of increased soluble sugars on hardiness. Perhaps too these effects due to changes in sugar cannot be clearly separated from the effects of the other changes which are going to be described because of circumstances which cause both to occur simultaneously in hardened tissues. Nevertheless, the arguments which will be presented here and even better evidence to be presented later (Table 2) suggest that the actual amount of soluble sugar in the cells cannot have much to do with large extremes of adaptation observed in the black locust cells.

In the first place changes in soluble sugars and hardiness can often be caused to proceed in opposite directions (Siminovitch and Briggs, 1954 and Table 2). It was also clearly evident as indicated in Fig. 2 and Fig. 3, that large quantities of soluble sugars accumulated in the cell in late summer long before the major hardening reaction began. Finally if the low temperature requirement in hardening was to be associated with the promotion of starch-sucrose conversions in the fall how could the fact be explained that high levels of starch were still present in the cells even into October when sugar concentration was not increasing and when hardening was proceeding inexorably and rapidly to a peak? The argument for an effect of the reverse sugar to starch transformation in spring was on the other hand, less easily dismissed. Any small rise in temperature beyond a certain point in spring, and the reaction was cumulative according to the temperature and its duration, was to cause a proportional quantitative reversion of sugar to starch with an immediate effect on hardiness (Siminovitch and Briggs, 1954). The effect on hardiness could also be reversed in spring with conversion of starch back 
to sugars by transfer of bark tissue to controlled temperatures at $+3^{\circ} \mathrm{C}$. In the light of what has been stated about the relation of concentration of soluble sugars to hardiness in the summer and autumn, the contradiction could only be resolved by invoking a hypothesis which, though it recognized this effect, found an explanation not in the increase in soluble sugars but in the diminution of the deleterious mechanical effects which starch granules may have had on the dehydrated protoplasm when the tissue was in its frozen state (Siminovitch and Briggs, 1954). It was easy to visualize this when the prominence of the starch granules in the cell at high starch levels and the degree of contraction of the cell experienced in freezing was considered. It was difficult then to explain why the existence of large concentrations of starch should have masked hardiness in spring and not in autumn. It was probable that in spring, real dehardening had already progressed to some extent. The reversal of dehardening observed upon transfer of bark tissue to low temperature was measured only by plasmolytic methods. It was clearly evident in autumn (Fig. 2 and Fig. 3) that the masking effects of starch on the major hardening processes were limited and would be revealed at that time only by scaling down of the hardiness test. Evidence of other chemical processes in the bark cells had to be found to account for the large change in hardiness in the black locust in October and the second type of seasonal changes occurring in black locust bark appeared to provide this evidence.

\section{Protoplasmic Synthesis in Relation to Resistance}

A series of studies on the black locust tree extending over a period of 10 years firmly established the fact that, in autumn, an abrupt transformation of the soluble protein and ribonucleic systems of the bark cells leading to a new net synthesis of water soluble protein and ribonucleic acid (RNA), coincided closely with the abrupt development of frost hardiness at this time (Siminovitch, 1963; Siminovitch et al., 1967). Peak levels of both protein and ribonucleic acid in the bark cells in winter were then observed to be associated with the maintenance of the fully hardy state at this time and these levels persisted until spring when with less precipitousness, but rapidly nevertheless, they declined concomitantly with the process of dehardening. A rhythmic annual cycle of variation in these constituents, similar and parallel to the cyclic variations in hardiness, has been observed to exist in the black locust tree and these cycles have not altered in 10 years of observation in the Ottawa area. A typical graph of these variations plotted against the period of maximum increment in hardiness as marked by the stippled region is shown in Fig. 4 (Siminovitch es al., 1967). Included in the graph are the variations in the desoxyribonucleic acid determined chemically and these showed a remarkable constancy in accord with the non-proliferative nature of the cells involved. The exact sequence of the ribonucleic acid and protein decreases in spring was not certain but the sequence of increases in autumn clearly indicated the precedence of the RNA change over the protein change in accord with the recognized catalytic role of RNA in protein synthesis. An increase in autumn in the capacity of the cells for incorporating amino acids into protein, demonstrated from incubations of small cubes of tissus in media containing either radioactive leucine or glycine, was also in accord with the proposed role of RNA in promoting protein synthesis at this time (Siminovitch and Chater, 1958; 


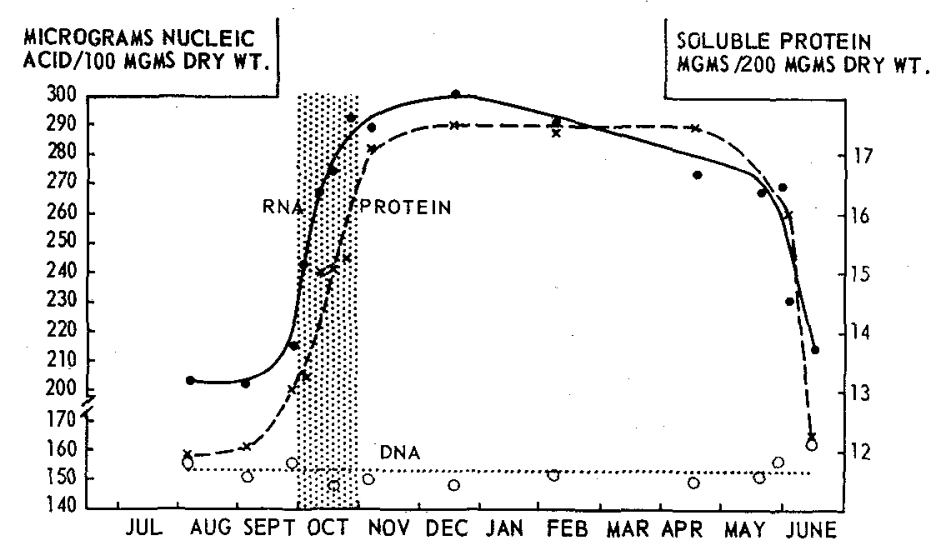

Fig. 4. Seasonal variations in water-soluble protein, ribonucleic acid and desoxyribonucleic acid in living bark. (Siminovitch et al., 1966)

Water-soluble protein was determined by the method of Lowry et al. (1951) after precipitation with $7.5 \%$ trichloracetic acid of the protein from the supernatant produced by the centrifugation at $20,000 \times g$ of a distilled water extract of $200 \mathrm{mg}$ lyophilized powdered bark

Ribonucleic acid was determined on $100 \mathrm{mg}$ lyophilized powdered bark by measuring the optical density at $260 \mathrm{~m} \mu$ of an extract made by a modification of the washing procedure of Ogur and Rosen (1950) and the alkaline hydrolysis method of Schmidt and Thannhauser (1945)

Desoxyribonucleic acid was determined on $20 \mathrm{mg}$ lyophilized powderd samples of bark by a modification (unpublished) of the fluorimetric method of Kissane and Robins (1958)

Siminovitch et al., 1967). The possible origin of the precursors activating the new protein and nucleic synthesis in autumn has been discussed elsewhere (Siminovitch and Briggs, $1953 \mathrm{~b}$; Siminovitch, 1963) and reason has been found to link the supply of these precursors with autumn senescence in the leaves and with the well known phenomenon of autumnal migration which takes place in deciduous trees at this time (Combes, 1925 ; Kramer and Kozlowski, 1960).

An abrupt process of new net synthesis of protein of this kind following upon ribonucleic acid synthesis and occurring in the absence of growth or cell division could only be interpreted to mean that a sudden process of protoplasmic augmentation was taking place in autumn during the period of greatest hardening. There was evidence even, although this was based only on comparisons of late winter with late summer cells, that this augmentation extended to the organelle components of the cell with consequent effects on the metabolism of the cell. The increase in RNA and the increased capacity for protein synthesis, as determined from rates of incorporation of amino acid, suggested, in the light of what was known of protein synthesis, that an increase in the ribosome content at least was taking place. Typical data showing more ribosomes in a winter tissue to match an increased capacity for incorporating amino acids into protein in these tissues is shown in Table 1 . Table 1 also shows a greater quantity of mitochondria in winter tissues corresponding to greater respiration rates in these tissues. It is of interest to note that an increase in chloroplast protein in hardened tissues has been observed (Heber, 1959 b).

It seemed logical to conclude, therefore, from the consistent evidence of association of increase in RNA and protein with hardiness and from the evidence already at hand 
Table 1. Mitochondrial and microsomal amounts and metabolic capacity. of summer and winter tissue (Siminovitch et al., 1967)

\begin{tabular}{lcccc}
\hline Date & $\begin{array}{c}\text { Respiratory capacity } \\
\text { Mitochondrial } \\
\text { protein } \\
(\gamma / 200 \mathrm{mg} \\
\text { fresh tissue })\end{array}$ & $\begin{array}{c}\text { Oxygen uptake } \\
(\mu 1 / \mathrm{h} / 200 \mathrm{mg} \\
\text { whole fresh } \\
\left.\text { tissue at } 25^{\circ} \mathrm{C}\right)\end{array}$ & $\begin{array}{c}\text { Protein synthetic capacity } \\
\text { Microsomal } \\
\text { protein } \\
(\gamma / 200 \mathrm{mg} \\
\text { fresh tissue })\end{array}$ & $\begin{array}{c}\text { Counts/min leucine-1- } \\
\text { C14 incorporated into } \\
\text { protein of } 800 \mathrm{mg} \\
\text { fresh tissue } / 4 \mathrm{hrs}\end{array}$ \\
\hline Early August & 187 & $20-40$ & 212 & 12,615 \\
Early March & 481 & $35-60$ & 337 & 19,575 \\
\hline
\end{tabular}

Mitochondrial and microsomal fractions were prepared by homogenization of fresh tissue cubes with a ground glass homogenizer using $10 \mathrm{ml} / \mathrm{g}$ tissue of a solution containing $0.4 \mathrm{M}$ sucrose, 0.05 $\mathrm{M}$ tris buffer at $\mathrm{pH} 7.7,0.005 \mathrm{M} \mathrm{MgCl}_{2}, 0.024 \mathrm{M} \mathrm{KCl}$. The cell wall debris and nuclear fractions were removed by centrifugation at $100 \times g$ for 10 minutes in a Servall SS-1 refrigerated centrifuge. The mitochondrial fraction was obtained in the pellet from the centrifugation at $20,000 \times g$ for 30 min of the supernatant of this centrifugation. The microsomal fraction was obtained in the pellet from the mitochondrial supernatant by centrifugation at $105,000 \times g$ for $2 \mathrm{hrs}$. Aliquots of the various pellet fractions were taken for protein nitrogen determinations by the method of Lowry et al. (1951)

Respiration was measured manometrically at $25^{\circ} \mathrm{C}$ in a Warburg respirometer on $200 \mathrm{mg}$ of fresh tissue cubes ( $2 \mathrm{~mm}$ on edge) suspended in $2.7 \mathrm{ml}$ White's salt solution containing $5 \%$ sucrose.

Incorporations were performed by $4 \mathrm{hr}$ open flask incubations at $25^{\circ} \mathrm{C}$ of $400 \mathrm{mg}$ lots of fresh tissue cubes ( $2 \mathrm{~mm}$ on edge) infiltrated and suspended in $5 \mathrm{ml}$ of White's salt solution containing $15 \%$ sucrose, 20 micrograms aureomycin, $2.5 \mathrm{mg}$ leucine and $2.5 \mu \mathrm{c}$ leucine-1-C 14 . After incubation the tissues were homogenized in a glass homogenizer with $10 \mathrm{ml}$ of a solution containing $0.4 \mathrm{M}$ sucrose, $0.05 \mathrm{M}$ tris buffer at $\mathrm{pH} 7.7,0.005 \mathrm{M} \mathrm{MgCl}_{2}, 0.024 \mathrm{M} \mathrm{KCl}$. The homogenate was centrifuged at $20,000 \times g$ in Servall SS-1 refrigerated centrifuge for $20 \mathrm{~min}$ to remove cell wall debris, nuclear fractions and mitochondria. The combined microsomal fraction and soluble proteins in the superanatant were precipitated with 7.5\% trichloroacetic acid (TCA). The precipitate was freed of nucleic acid and lipides by extraction and washing with hot TCA, alcohol-ether at $65^{\circ} \mathrm{C}$ and then ether before solution in $1.0 \mathrm{ml}$ of formic acid. The formic acid solution was plated on a stainless steel planchet and dried before counting in a thin-window Nuclear-Chicago counter

of differences between winter and summer tissue in organelle components and metabolic capacity, that augmentation of all cell components was occurring during hardening and that this replication of cell structures and membranes was occurring as part of the mechanism of freezing resistance. It should be noted in fact that the methods which were employed in most of these studies to obtain the water-soluble protein fraction involved the extraction of lyophilised powders with distilled water. Such conditions of extraction would inevitably lead to lysis and disruption of cell structures and organelles and liberation of part of the structural protein into solution. Thus the observed increases of water-soluble protein with hardening might have been accounted for in part by the increase in the structural elements of the cell. The true soluble protein of the cells should really have been determined in the supernatant of a buffered sugar homogenate, of fresh tissue after high-speed centrifugation. It is conceivable therefore that if the increases in the structural or membranous protein components of the cell were the more crucial elements in the hardening mechanism that conditions might be found where these elements showed a better correlation with hardiness than would the true soluble protein fraction. - It was even conceivable that an increase in the protoplasmic membrane substance itself was involved and such a possibility would be consistent with primary 
localization of the physical changes which were associated with tolerance to dehydration in the plasma membrane, although just how this would be caused was difficult to surmise.

\section{Cellular Evidence of Protoplasmic Synthesis}

Cytological evidence has also been obtained for this protoplasmic augmentation. Indeed the independent evidence gained from cytological studies of increase in both cytoplasmic and nuclear substance in fall and winter and of the association of these increases with hardening was convincing (Siminovitch and Chater, 1958; Siminovitch et al., 1967). Augmentation could be followed in vitally stained cells (neutral red) with the ordinary microscope or in fixed cells with the phase contrast microscope with considerable degree of confidence and because it coincided with hardening, permitted a rough but simple visual assessment of hardening in the cell. This is illustrated in. Fig. 5 which contains photographs of neutral red stained cells in the extreme conditions of low hardiness (summer) and high hardiness (winter). In the summer very little could be observed other than a large vacuole stained red and some mitochondria streaming in the thin
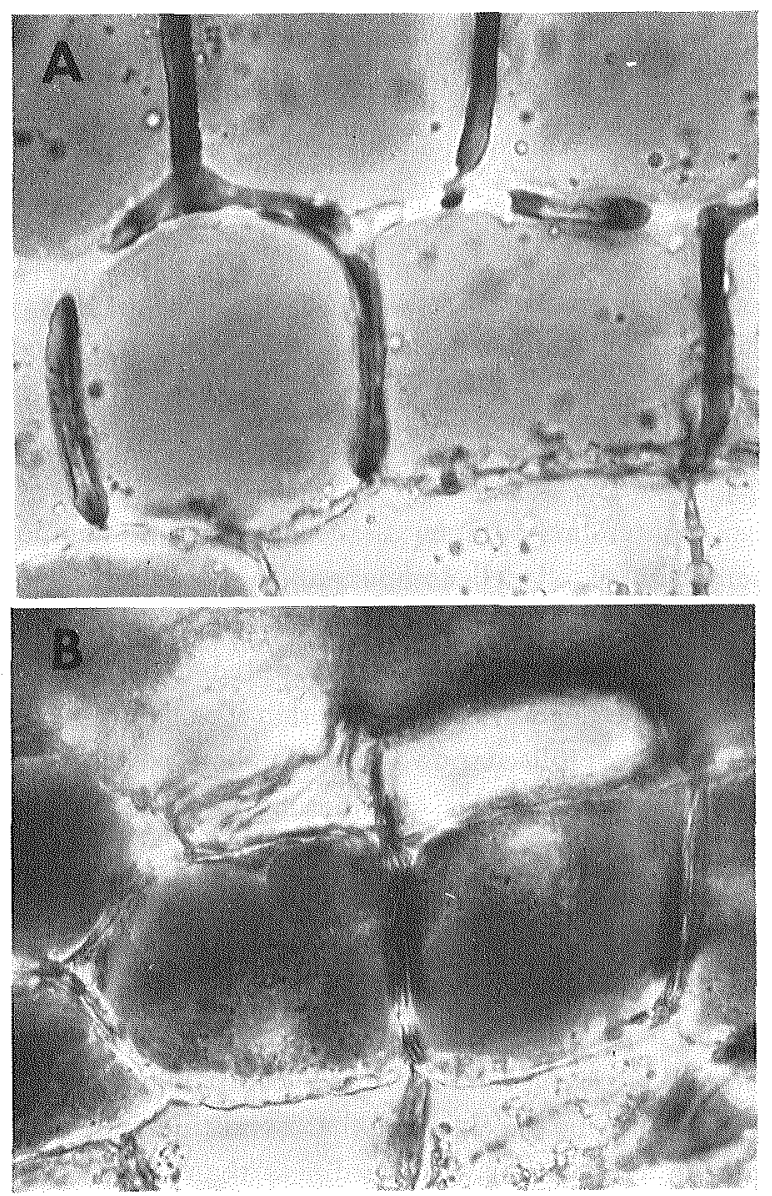

Fig. 5. Photographs of vitally stained (neutral red) summer A and winter B black locust bark cells. $\times 1000$ (Siminovitch et at., 1967) 


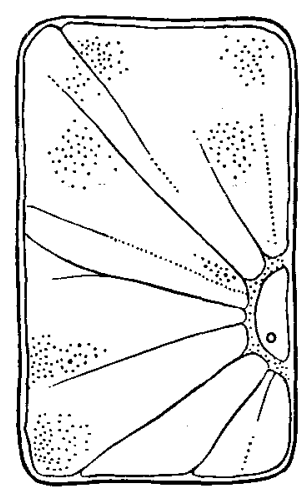

SUMMER

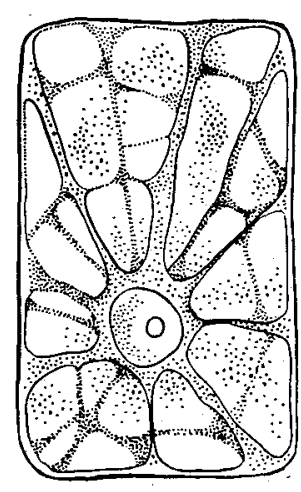

WINTER

Fig. 6. Diagrammatic representation of summer and winter aspects of living bark cells (Fixation with alcohol-acetic acid). $\times 1800$ (Siminovitch et al., 1967)

peripheral cytoplasm. It was difficult to perceive the nucleus. In winter the unstained nucleus and cytoplasmic strands radiating out from it to the cytoplasm stood out in vivid contrast to the background of the red vacuole. Even the nucleolus was discernible in the winter nucleus. When it is considered how tenuous the peripheral cytoplasm is in a mature plant cell like this, the contrast in winter cells must reflect a considerable increase in the density of the cytoplasm and nucleus arising out of augmentation of cytoplasmic and nuclear substances. Fixation with alcohol-acetic acid brought this contrast out even better and a diagrammatic sketch of the appearance of winter and summer cells is shown in Fig. 6. Such fixed winter cells suggested that the nucleus was not only denser but larger, spherical in shape and centrally located. In summer the nuclei were not only smaller and less dense but more lens-shaped and usually laterally located in the cell.

The whole pattern of cytological and chemical changes shown to be associated with the periodic transition of summer cells to hardy winter cells conveyed the impression of involvement of freezing resistance with augmentation of protoplasmic substance. The most striking feature of these changes was their characteristic suddenness and coincidence but our evidence for a causal relationship of protoplasmic augmentation and hardiness was not based simply on coincidence and correlation.

\section{Graded Levels of Protoplasmic Synthesis in Starvation in Relation to Resistance}

The effect of the imposition of artificial restriction of the supply of precursors for protein synthesis in the bark on the progress of hardening had been examined for some time. For this approach the simple expedient was used of girdling or ringing the tree down to the wood so as to prevent translocation from the leaves to sites of tissues under study. This procedure was used as indicated in Fig. $7 \mathrm{~A}$ to considerable advantage at first (Siminovitch and Briggs, $1953 \mathrm{~b}$ ) but a modified procedure has been adopted since because of certain difficulties encountered with girdling. Complete ringing of the bark in summer ultimately killed the tree and it could be used for only a single seasonal study. 
It also caused excessive accumulation of food substances above the ring so that the effects of varying degrees of starvation could not be examined by insertion of successive girdles at different times and levels on the same tree. Later it became necessary for different trees to be used for each girdling experiment and differences between tree individuals caused variability in our results. The device was then used of completely encircling an island of bark tissue by excision of a rectangular band of bark as indicated in Fig. 7 B. Such an island of tissue was as effectively deprived of contact with the translocating channels of the trunk as was a ringed section. The remaining part of the tree was now normal in every respect and any number of samplings or encirclements could be made subsequently on the same tree without damage to the tree. The introduction of the new method of testing for frost hardiness and the new procedure for performing successive isolations on the same tree trunk permitted the examination, with more conviction, of the effect of varying degrees of starvation on protoplasmic synthesis and hardening. Periodic isolations of this kind yielded

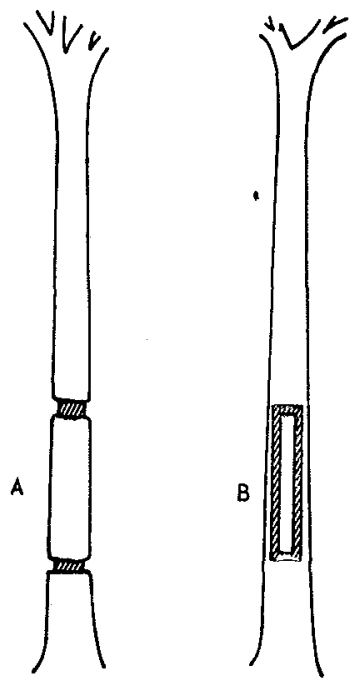

Fig. 7. Methods of progressive starvation of segments of living bark of the trunk of the black locust tree in summer as in

A by insertion of girdles above and below the segments and periodically by insertion of additional girdles up the trunk; or as in

$B$ by periodic encirclements of fresh island segments of bark on the trunk with a debarked area a series of tissues with graded levels of starvation and afforded some interesting relationships. Some of these relationships were recognized in a vague sort of way from early work but now assumed some considerable significance in relation to the hardiness problem. In most cases ringing or isolations were performed in August or September and the relationships being looked for were examined either in November or December when as indicated in Fig. 2, normal hardening had been nearly completed in normal treès. Sampling for hardiness tests, chemical analysis and metabolic studies were therefore taken both at the time of isolation and at the time when hardening was complete in November.

When girdling or isolations were performed too early in summer as in early July; there were indications by November of excessive depletion due to respiration and metabolism of the sugars originally translocated. Such severely depleted tissues were too sensitive to any kind of treatment especially freezing and could not be used. In sections isolated after early August, there were sufficient sugars to permit survival well into the hardening period. Such tissues exhibited remarkable vitality in spite of the long period of deprivation and if left on the tree survived well into November or December. Fig. 8 shows typical results of the effects of double-girdling performed in August on the hardiness changes from August to November in the part of the trunk between the rings and in the part above the rings as measured by the ninhydrin method. If these hardiness values are compared with the plots in Fig. 1 and Fig. 2 it can be perceived that the 


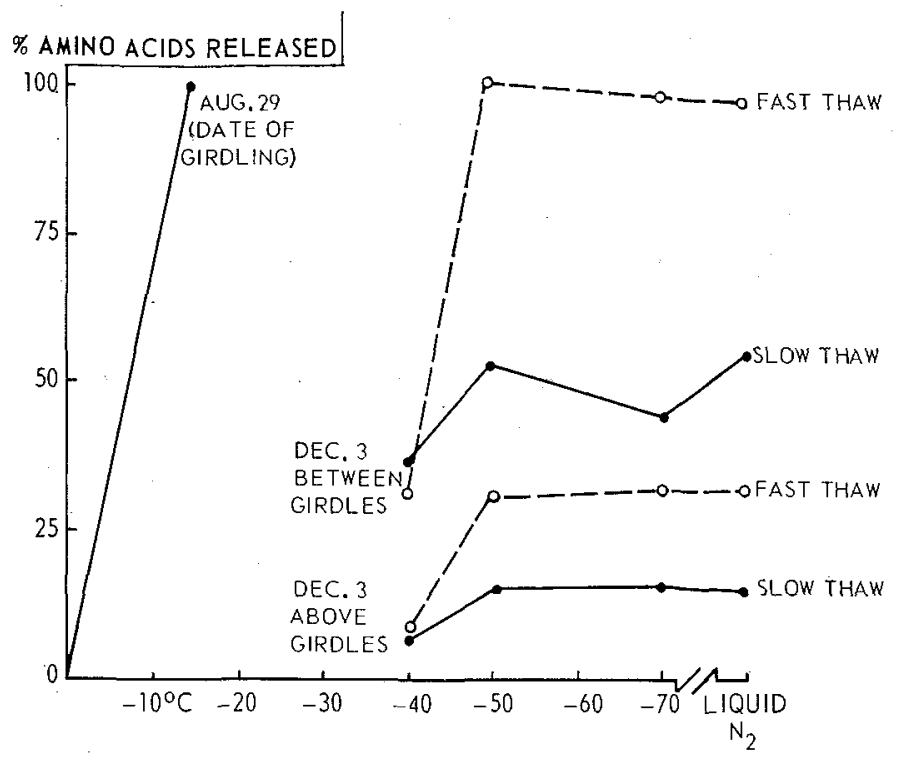

Fig. 8. Effect of double girdling (as in Fig. 7 A) in August on the subsequent winter (Dec. 3) hardening of a starved section of living bark located between girdles as compared with normal progress of hardening in the unstarved section of the trunk located above the girdles. Hardiness determined as in Fig. 1 but with both slow and fast thawing

hardiness in the parts of the trunk above the rings is nearly normal due to access of this part to translocated material from the leaves while the hardiness in the girdled section between the rings is limited. Rapid thawing as indicated in Fig. 8 better served to bring out the distinction between the hardiness of the normal and girdled sections of the tree. The girdled section while it showed vitality and tolerated a single slow freeze to $-50^{\circ} \mathrm{C}$ would have eventually succumbed under natural conditions if left out-doors through the winter due to the succession of freezings and thawings at more moderate freezing temperatures. It was apparent nevertheless that when the hardiness of this isolated section was compared with its original hardiness when isolated in August that a remarkable degree of hardening had occurred in spite of the degree of its deprivation of sugars and of other translocated nutrients. Similar results were obtained when the tissues were isolated by encirclement after excision of a band of bark in August (see later Fig. 12).

Tissues restricted either by girdling or encirclement, in August, therefore had already acquired a remarkable potential to harden off even under starvation. If now, new areas or islands of bark tissue were encircled on the same trunk but at later dates it was noted that the potential for hardening in these tissues at the time of isolation became progressively greater from August on so that when isolated in late September even though normal hardening had not yet occurred these tissues already possessed the potential for almost complete hardening. This growing potential is portrayed somewhat schematically in Fig. 9 with black circles representing a series of successive bark isolations made on dates indicated by corresponding points on the abscissa and with hardiness at the time of isolation indicated on the ordinate. Since each isolation was made in the normal region of the trunk, the line joining these black circles simply represents the 


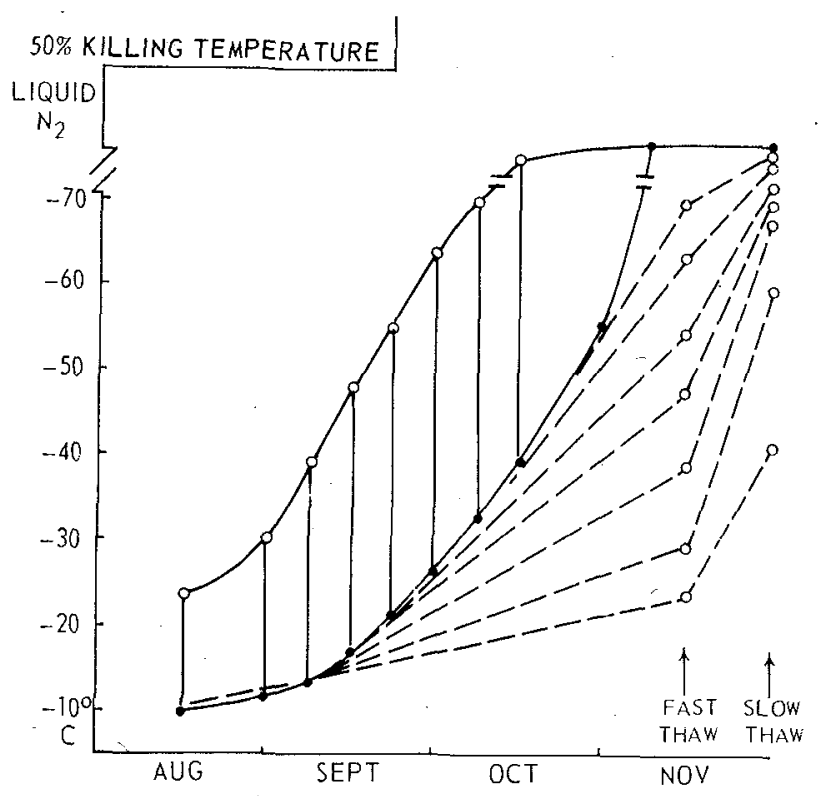

Fig. 9. Changes in hardiness in early fall in bark segments of the black locust periodically isolated on the trunk in summer by encirclement within a debarked area. Each black circle represents a fresh isolation on the trunk with the date of isolation being indicated by the corresponding point on the abscissa and the hardiness at the time of isolation by the corresponding point on the ordinate. Each white circles joined by a solid or dashed line to a black circle indicates the hardiness reached in November in the segment represented by the black circle. Hardiness was determined as in Fig. 1 but included a fast thaw in November

progress of normal hardening in that tree. The white circles on the right represent the hardiness attained by each section in November as determined from both slow and fast thawing tests and the dashed line joining the black and white circles shows the overall change in hardiness in that section. The actual potential at the time of isolation was better discerned by the drawing of a vertical line upwards from the black circles to the points; also indicated by white circles, corresponding to what the hardiness was in November using only the fast thawing results. The reason for showing the potential for hardening in this way rather than by using the slow thawing results was that as the capacity for hardening increased in seasonally later isolations it became increasingly difficult with slow thawing to discriminate between the hardiness of the various sections. If the black circles had been joined vertically instead to white circles corresponding to the hardiness as determined in November by slow thawing, the lines would have been extended further upwards and would have shown an even greater potential for hardening in early isolated sections. The method of plotting used is adequate nevertheless for portraying the striking gradations in levels of hardiness which can be produced artificially by progressively deferring isolations of the bark sections. A figure roughly similar to that shown in Fig. 9 would have emerged from plotting our earlier published results of progressive girdling up the trunk (Siminovitch and Briggs, $1953 \mathrm{~b}$ ).

Except in one important instance, which will be illustrated below, comprehensive 
Table 2. Changes during autumn in the frost hardiness, total soluble sugars, proteins, ribonucleic acid, protein synthetic capacity and phospholipides in normal and summer isolated bark tissues

\begin{tabular}{|c|c|c|c|c|c|c|}
\hline Tissue & $\begin{array}{c}\text { Hardiness } \\
\text { (killing temp) }\end{array}$ & $\begin{array}{c}\text { Total } \\
\text { soluble } \\
\text { sugars } \\
\text { (\% dry wt) }\end{array}$ & $\begin{array}{l}\text { Soluble } \\
\text { protein } \\
\mathrm{mg} / 100 \mathrm{mg} \\
\text { dry weight }\end{array}$ & $\begin{array}{c}\text { RNA } \\
\text { r/100 mg } \\
\text { dry weight }\end{array}$ & $\begin{array}{l}\text { Counts } / \mathrm{min} \\
\text { leucine- } 1-\mathrm{C}^{14} \\
\text { incorporated/ } \\
400^{\circ} \mathrm{mg} \text { fresh } \\
\text { tissue } / 4 \mathrm{hrs}\end{array}$ & $\begin{array}{l}\text { Phosphorus }(\gamma) \\
\text { in chloroform } \\
\text { extract of } 300 \\
\text { mg dry tissue }\end{array}$ \\
\hline August normal & $-15^{\circ} \mathrm{C}$ & 7.2 & 3.7 & 218 & 5,650 & 32.3 \\
\hline $\begin{array}{l}\text { August-November } \\
\left(\text { at }-5^{\circ} \mathrm{C}\right) \text { (excised) }\end{array}$ & $-25^{\circ} \mathrm{C}$ & 6.9 & 3.7 & 220 & 一 & - \\
\hline $\begin{array}{l}\text { August-November } \\
\text { (encircled) }\end{array}$ & $-45^{\circ} \mathrm{C}$ & 2.1 & 3.9 & 221 & 6,150 & 56.3 \\
\hline November normal & $\begin{array}{l}\text { Liquid } \\
\text { nitrogen }\end{array}$ & 9.1 & 7.5 & 312 & 15,025 & 63.8 \\
\hline
\end{tabular}

Hardiness was determined as in. Fig. 1, soluble sugars as in Fig. 3, water-soluble protein and ribonucleic acids as in Fig. 4, and incorporation rates as in Table 1

For determination of the phospholipids $300 \mathrm{mg}$ of lyophilized powdered bark were extracted for 3 hrs with ethyl alcohol: ether:: $3: 1$. The ether was evaporated off and the extract was then shaken with chloroform and water (final volumes were 1 of ethyl alcohol: 1 of chloroform: 3 of water). The top layer of ethyl alcohol and water was removed and phosphorus was determined in an aliquot of the remaining chloroform layer

studies of the carbohydrate changes in the tree used in the hardiness study described in Fig. 9 or of any other tree progressively starved by encirclement have not yet been made. It is sufficient for purposes of the present report to anticipate what these would have been from results which have been obtained on trees progressively starved by girdling and which have been reported in an earlier publication (Siminovitch et al., 1953). It will be obvious that in tissues starved by girdling or encirclement in midsummer and with respiration proceeding at high temperatures, a depletion of carbohydrates would occur. Tissues isolated by girdling in August did show in fact considerable depletion (Siminovitch et al., 1953). A similar result was obtained in the one set of analyses performed on tissues starved by encirclement see (Table 2) at this time. As would be expected also depletion of sugars in girdled tissues became progressively less pronounced with deferment of their isolation to late August or September due to prolongation of normal contact with the translocating channels and to the consequent increased extent of accumulation of sugars and starch in the cells prior to isolation. By November or December such tissues showed very little starch but the levels of sugars remained either constant or increased slightly but not to a degree which would account for the large change in hardiness. As in normal trees, the amount of soluble sugar remaining in November did not account for all the starch which disappeared; In general it could be stated from the early carbohydrate studies performed on trees starved by girdling that the soluble sugars in all isolated sections either showed an inverse relationship to changes in hardiness or at best no relationship at all. There is no reason to believe that the encircled tissues would have behaved differently.

Studies of the changes in the soluble proteins and ribonucleic acids in the encircled sections of the tree used for the hardiness study in Fig. 9 were made. These studies confirmed and extended the results obtained in earlier starvation experiments using 


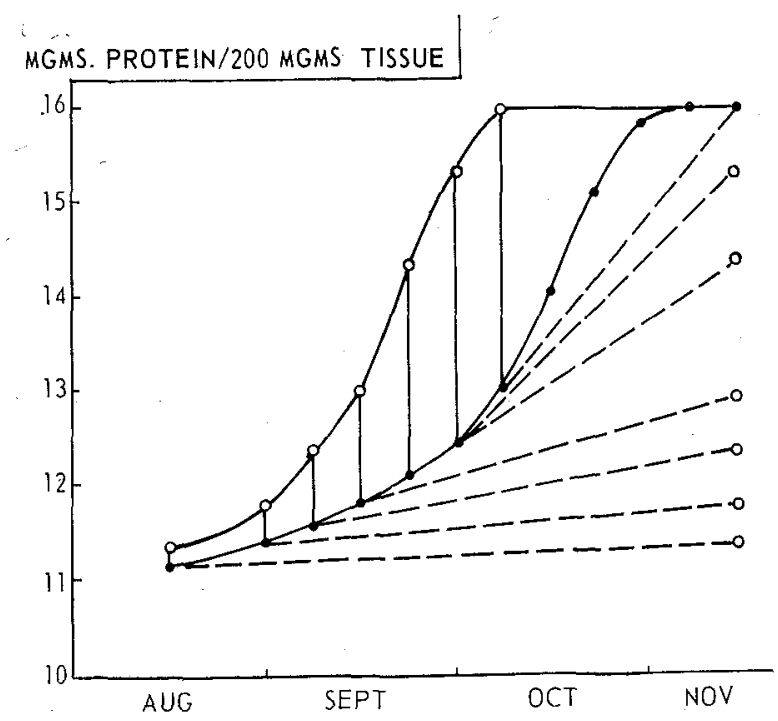

Fig. 10. Changes in water-soluble protein (per $200 \mathrm{mg}$ dry weight tissue) in early fall in the same bark segments used to study the effect of isolation on hardiness as depicted in Fig. 9 . The changes in protein in each segment are indicated in the same manner as in Fig. 9 but with the black circles now being the values of protein at time of isolation and the white circles the value of protein in November. Protein determined as in Fig. 4

girdling (Siminovitch et al., $1953 \mathrm{~b}$ ). When the soluble protein values were plotted against the date as in the hardiness graph shown in Fig. 9, with the value of protein at the time of isolation represented by black circles, the values in November by open circles, the overall changes by the dashed line and the potential change by the vertical lines joining the black and white circles, the graph which was finally obtained (Fig. 10) showed, with but one discrepancy, a remarkable correspondence with the graph obtained in the hardiness results. This discrepancy consisted of the fact that there was little increase in protein in the section isolated in August even though hardiness increased markedly. As the isolations were deferred, the tissues after isolation began to show an increasing potential for increasing the quantity of soluble protein and both the net increment and final value for total soluble protein from the time of isolation to November was remarkably proportional to the increase in capacity for hardening which they now had beyond that which they had in August.

Analyses have not yet been made to determine whether the increase in soluble protein subsequent to isolation was due entirely to new synthesis of protein proceeding, after isolation, from amino acids already accumulated at the time of isolation or whether there was in fact some conversion of insoluble protein to soluble protein. The resolution of this problem is obviously important in the light of the postulated role of increase of total protoplasm in hardening. A conversion of insoluble protein to soluble protein might suggest that the kind of protein rather than the amount of total protein was involved in hardening. However, in normal trees, the increase which occurred in autumn in soluble protein was never associated with diminution in insoluble protein or in nonprotein nitrogen and was always reflected in an increase in total nitrogen. It was also 
evident since early girdling or encirclements caused total restriction of soluble protein increase that this restriction must have been due to lack of amino-acids normally translocated from the leaves. Correspondingly, the progressive development during the summer and autumn of increased capacity for increase in soluble protein in the bark tissues must have been due to the mounting influx of essential amino-acids and catalysts for protein synthesis prior to isolation. It can be safely assumed therefore that the increased levels of protein established finally in the bark with progressive deferment of isolation was due to increasing levels of net protein synthesis in the bark cells. Experiments now with 10 different trees over a period of several years have always yielded the same relationships and shown that beyond the certain degree of hardiness which is obtained in August isolations, any degree of hardiness or protein content can be achieved at will according to the time of isolation. Obviously protoplasmic increase as reflected in watersoluble protein accumulation is distinctly correlated with hardiness.

The results with the ribonucleic acid (RNA) in the isolated sections of this tree when represented graphically in the same manner as in Figs. 9 and 10, were, as shown in Fig. 11 , in accord with the results with the studies on hardiness and protein except in respect

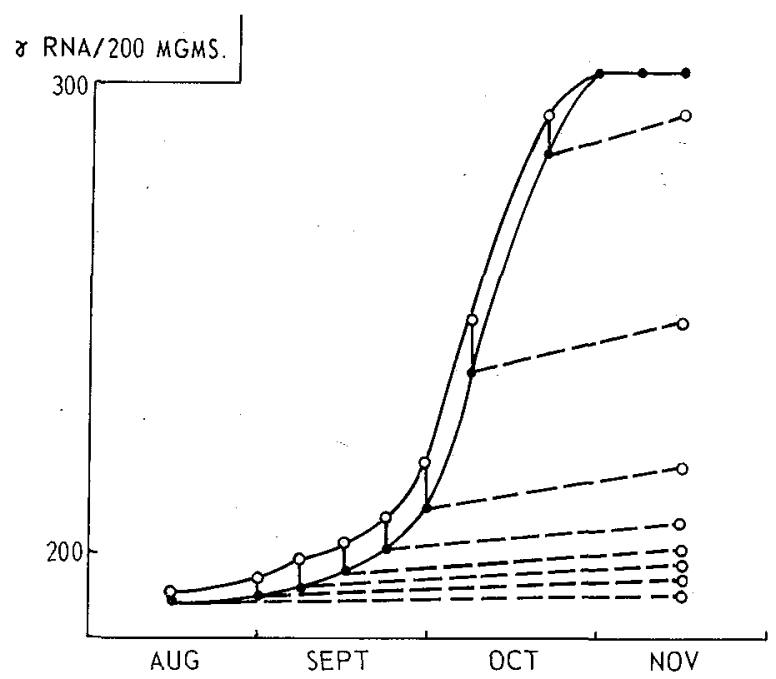

Fig. 11. Changes in total ribonucleic acid (RNA) (per $200 \mathrm{mg}$ fresh weight tissue or per $100 \mathrm{mg}$ dry weight), in early fall in bark segments of the trunk after isolation. The same segments were used as in Figs. 9 and 10. The values and changes in RNA are represented exactly as for proteins in Fig. 10. Ribonucleic acid determined as in Fig. 4

to one important property. Gradations in degree of RNA content due to different degrees of restriction of translocation of what presumably must be precursor nucleotides were obtained in the periodically isolated sections, but the tissues did not exhibit at any time the same potential for continued synthesis of ribonucleic acids after isolation as they did for synthesis of protein or hardening.

Difficulties were presented in relation to the assumed role of RNA as a catalyst for protein synthesis and added weight to the argument that continued synthesis of protein in the early isolations was not due to true synthesis of protein but conversion of insoluble 
to soluble protein. This argument, for reasons already mentioned, could not apply to later isolations. The difficulty was that in the tissue isolated in late summer or early fall the RNA was already beginning to increase along with the increasing potential for hardening and protein synthesis. This problem requires further study but the important result was that a series of tissues with distinct gradations in RNA content was finally obtained and these gradations varied according to the time of their encirclement. In this respect the results were not in conflict with the proposed role of total protoplasmic increase in hardening.

\section{The two-fold Nature of the Principal Processes of Hardening}

Several facts of considerable significance emerged therefore from the studies of restricted nutrition in girdled or isolated sections of tree bark. The first fact was, that under conditions of almost complete restriction of net protoplasmic synthesis in summer tissues, a considerable level of hardiness could still be achieved. The second fact was that in later isolated tissues, new potentials for hardening were acquired and new levels of hardiness were ultimately reached first according to the increment in soluble protein and perhaps later according to the increment in ribonucleic acid as well. In the absence of growth or cell division these increments had to be interpreted as being increments of protoplasm which included all protoplasmic components. When we coupled these facts to the observation that nearly complete hardening was under normal conditions closely linked in its timing with protoplasmic synthesis, it had to be concluded that two distinct reactions were involved in hardening, one of which, operating completely independently of the other under conditions of starvation, did not require protoplasmic augmentation while the other which operated in normal trees required this augmentation reaction as well as perhaps the first reaction as a complementary reaction to it to effect complete hardening. A reasonable extrapolation was that different environmental temperature conditions could have affected these two reactions and that for complete hardening to be expressed both sets of conditions were required. This did not exclude the possibility of endogenous rhythmic mechanisms controlling either one or both of these reactions more or less independently of temperature.

\section{Protoplasmic Augmentation as a Rhythmic Process in Hardening}

It is well established now that a period of chilling or sub-zero temperatures is required for the normal hardening of most plants although it is not always recognized, in normal trees at least, that assimilation of energy substrates and mobilization of the precursors necessary to synthetic reactions in hardening is likely to be favoured by a period of higher temperatures. In the autumn the phenomenon of translocation to the bark and transformation there of these precursors to protein and ribonucleic acid may also constitute a process in hardening which is independent of low temperature. Protoplasmic augmentation took place regularly and reproducibly from year to year in October regardless of extended periods of high temperature which occasionally prevailed in October in our climate. Moreover the drop in average temperature during that month was always 
much more gradual than the rate at which new net synthesis of protein and nucleic acid occurred and it was difficult to relate low temperature to these syntheses. It is likely therefore that the process of total protoplasmic synthesis is controlled rather by an endogenous rhythmic mechanism which is more or less independent of temperature and is triggered off by a photoperiodic response in the leaves. Experiments with young trees maintained at constant temperature conditions should help resolve this question.

\section{Hardiness Without Protoplasmic Augmentation as a Low Temperature Process}

If then protoplasmic synthesis were independent of low temperature, the question presented itself as to the hardening process or stage in tree cells in which lay the well recognized requirement for low or even sub-zero temperatures. It was difficult in the normal tree to determine this requirement because the final stages of protoplasmic synthesis and hardening were not reached until early November and by that time some periods of freezing temperatures had already been experienced by the bark tissues especially during the night. It was not known how far then the rhythmic processes in relation to augmentation of protoplasm could independently forward the hardening reaction before the low temperature requirement set in. The following results with the starved tissues in the encircled sections and experiments with bark tissues excised completely from the tree and with winter wheat have shed some light on this problem.

It was not known exactly what temperature conditions prevailed when the hardening reaction occurred in the severely restricted bark sections in situ. There was however clear evidence from studies made of sections of tissue excised completely from the tree in August and kept in polyethylene bags at temperatures of $-5^{\circ} \mathrm{C}\left(23^{\circ} \mathrm{F}\right)$, that part of these conditions must have been sub-zero temperatures. The hardiness developed by November in such excised tissues in storage at $-5^{\circ} \mathrm{C}$ is shown in Fig. 12 along with the results of hardiness tests of a) the tissue in August before storage; b) of tissues

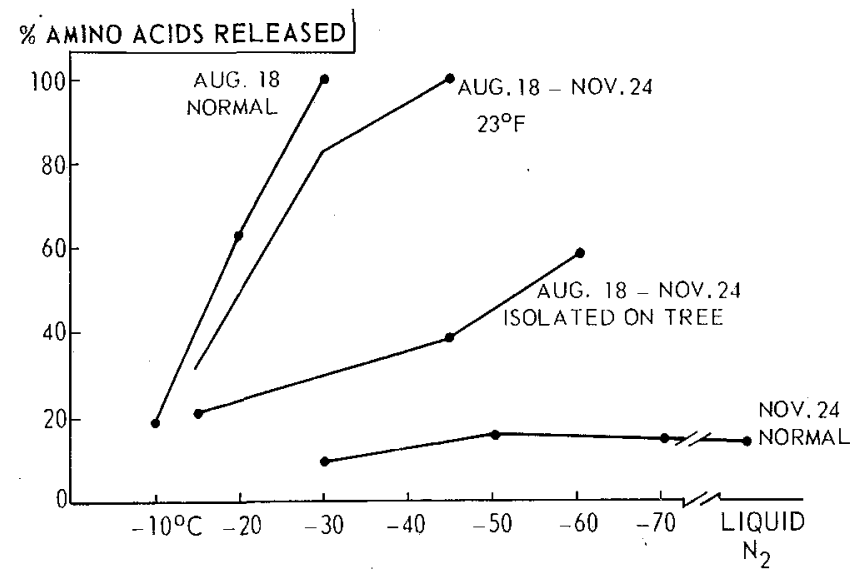

Fig. 12. Effect of isolation in August of bark sections of the trunk by a) encirclement in situ as in Fig. $7 \mathrm{~B}$ or by b) total excision and storage at $-5^{\circ} \mathrm{C}\left(23^{\circ} \mathrm{F}\right)$ on the subsequent winter hardening (Nov. 24) as compared with the normal progress of winter hardening in unstarved normal parts of the trunk. Hardiness determined as in Fig. 1 
taken from sections of the same tree which had been encircled in August and left in situ until November; and c) of tissues of the normal part of the tree in November. It is evident that an appreciable degree of hardiness developed in completely excised tissue in storage at $-5^{\circ} \mathrm{C}$ although as Fig. 12 shows and as was indicated in previous data (Fig. 9) this hardiness is not as great as that of the encircled tissue left on the tree. The hardiness in these isolated and encircled tissues relative to that which they had previous to storage and encirclement is not adequately conveyed by the plots in Fig. 12 because the hardiness results for the normal August tissus was not truly representative in this one instance of the hardiness of a summer tissue. A fairer indication of this increase would be obtained by comparing their hardiness in November with the more typical results of hardiness tests of normal bark tissue in August shown in Figs. 1 and 8 .

If then as the analyses of the protein and RNA changes showed (Figs. 10 and 11) that tissues encircled in August, having been deprived of translocated nutrients, were completely hindered in protoplasmic augmentation, it had to be assumed that the expression of the potential for hardening must have been elicited in these tissues, as it was in the completely excised tissue, only by the eventual exposure of these tissues to freezing temperatures which outdoors occurred in late October or November. The only difficulty here was that hardening in the encircled tissues was appreciably greater than that of the excised tissues. This could not have been due to the periods of high temperatures to which the encircled tissues would have been exposed in late summer because the hardiness of excised tissues maintained for prolonged periods of temperatures ranging from $-1.7^{\circ} \mathrm{C}$ and higher always diminished in proportion to the increase in temperature. It appeared that maintenance of starved tissues outdoors in situ on the tree offered better conditions for receiving the subsequent conditioning at sub-zero temperatures than did continued storage at sub-zero temperature even though the period of exposure to these sub-zero temperatures was greater in the excised tissue than in the encircled tissue. Whatever the reason for this difference between encircled and excised tissues the evidence points to low or sub-zero temperatures as being the conditions required for the hardening reaction which occurs in the starved tissues in the absence of protoplasmic augmentation. It must be assumed therefore that while the first phase of hardening in a normal tree is independent of low temperature up to the near completion of protoplasmic synthesis, subsequent hardening must depend on sub-zero temperatures to further a reaction which corresponded to that which occurred in the encircled or excised tissues.

Even better evidence of a specific freezing temperature requirement for hardening had been obtained from studies on winter wheat seedlings. Winter wheat seedlings will harden off to a certain extent at temperatures of $+2^{\circ} \mathrm{C}$ if grown in the light but if this wheat is transferred to $-3^{\circ} \mathrm{C}$ in the dark and maintained for two weeks

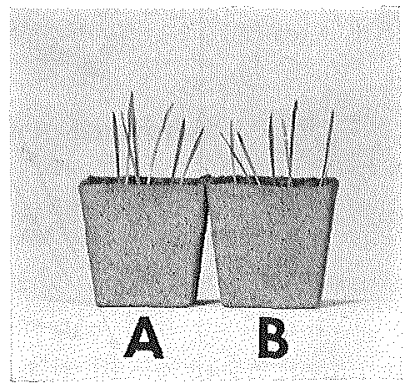

Fig. 13. Extent of growth of seedlings of variety Kent following germination

A during hardening for 8 weeks at $+2^{\circ} \mathrm{C}$ with light

$\mathrm{B}$ during hardening for 6 weeks at $+2^{\circ} \mathrm{C}$ in light and then 2 weeks at $-3^{\circ} \mathrm{C}$ in darkness 


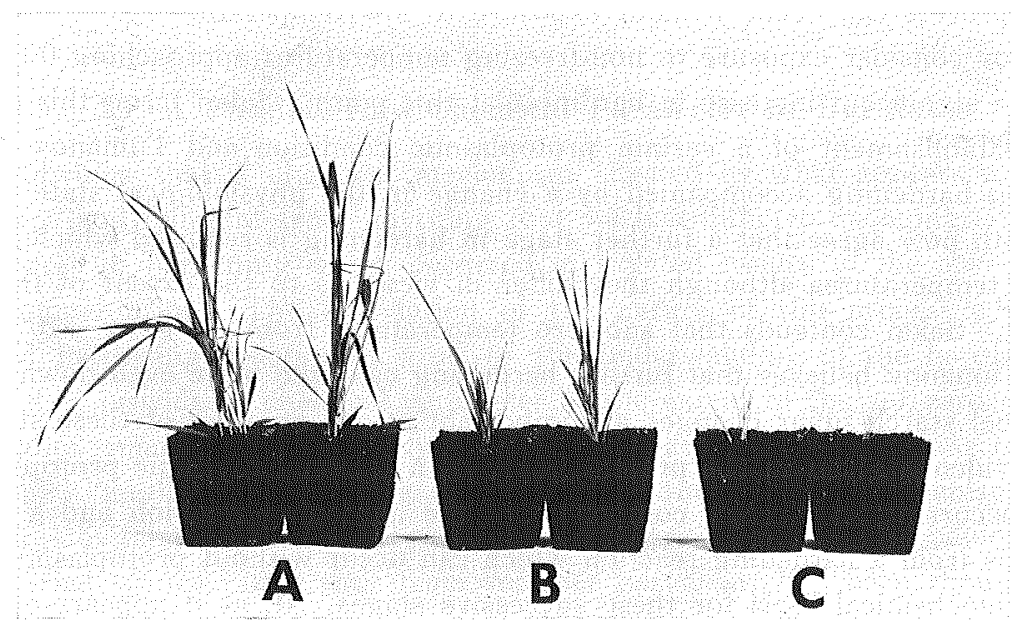

Fig. 14. Survival and growth in the greenhouse of hardened Kent seedlings after freezing test

A Control unfrozen, previously hardened either as in B) or C)

$\mathrm{B}$ Frozen to $-13^{\circ} \mathrm{C}$ after period of hardening for 6 weeks at $+2^{\circ} \mathrm{C}$ in light and two weeks at $-3^{\circ} \mathrm{C}$ in darkness

C Frozen to $-13^{\circ} \mathrm{C}$ after period of hardening for 8 weeks at $+2^{\circ} \mathrm{C}$ in light

at this temperature it will harden off further. There was no difference between the growth of the seedling wheats at the termination of a period of hardening at $+2^{\circ} \mathrm{C}$ and after termination of a similar period of hardening which included 2 weeks at $-3^{\circ} \mathrm{C}$ (Fig. 13). If now these seedlings were frozen to $-13^{\circ} \mathrm{C}$, there was much less injury and less retardation of growth in seedlings experiencing the extra hardening at $-3^{\circ} \mathrm{C}$ (Fig. 14). Similar results had been obtained on cabbage hardened in the dark, by Levitt, and his co-workers (Kohn and Levitt, 1965). They also observed that the cabbage hardened off without increase in osmotic potential. Hardening of the winter wheat plant like other herbaceous plants requires light for assimilation in the first phase of hardening but it also needs cold during this phase. This initial hardening period appears to be analogous to the assimilatory and synthetic phases of trees which occurred at higher temperatures. Cold is also required in this phase of hardening of the herbaceous plants because unlike trees, where inherent periodic rhythms caused cessation of growth even at high temperatures at the end of summer, growth must have been slowed down or arrested by low temperatures to have permitted the protoplasmic accumulation phase to occur.

\section{The Multiple Processes in Resistance}

We are therefore at the interesting juncture in the study of the hardening mechanism where a clear resolution is possible of the hardening mechanism into at least two separate biochemical processes or phases which show different temperature responses. Sakai $(1963,1966)$ and Tumanov (1963) have also inferred, on the basis of differential temperature responses in other woody plants, the existence of separate phases and processes in hardening. Both Sakai and Tumanov have recognized the existence of a preparatory process of seasonal periodicity, without which process there can be no real hardening 
and which process can occur without exposure to low temperature although both Sakai and Tumanov consider exposure to non-freezing temperatures approaching $0^{\circ} \mathrm{C}$ is needed to produce a significant increase in hardiness at this point. Sakai terms this preparatory stage the establishment of a certain protoplasmic condition and Tumanov calls it the first stage in hardening accompanied by a change in the physiological state of the protoplast. Both now agree that a further stage in hardening is required which is exposure to sub-zero temperatures although they differ in views as to the extent of this sub-zero requirement. Sakai contends that sub-zero temperatures from $-5^{\circ} \mathrm{C}$ to $-10^{\circ} \mathrm{C}$ are optimum and Tumanov believes that further hardening can take place even down to $-60^{\circ} \mathrm{C}$. Both also feel starch-sugar changes are important at one or other of these stages. The combined evidence given in the present paper of a seasonal rhythmic protoplasmic augmentation occurring as a major component of the hardening reaction and a clear separation of this from a hardening reaction which can occur without protoplasmic synthesis provides a biochemical basis for these successive stages. If, as it appears on the basis of the present evidence, protoplasmic augmentative reaction is rhythmic and more or less independent of low temperature while the non-augmentative one requires sub-zero temperature and that both are required for the total expression of hardiness in a normal tree then a basis is provided also for the multiple temperature responses which have been observed during the hardening of the black locust and other plants. Both reactions should be considered as protoplasmic because it will be shown that in neither of these reactions can starch-sugar changes be considered to play a prominent part. This does not mean as was indicated earlier that the starch-sugar transformations must be discounted as a factor in hardiness, because the fact remains that at low or moderate levels of hardiness as in early fall and in late spring starch-sugar changes do affect hardiness. The suggested reason for this is that high levels of starch in the cells do diminish hardiness (Siminovitch and Briggs, 1954). In this sense the starch-sugar conversion provided by low temperatures must be categorized as a third hardening process, which in autumn must partly fill the low temperature requirement in the total hardiness mechanism of plants. The data shown in Table 2 , however, which contains in summary form analyses performed on the same excised and encircled tree tissues used for obtaining the hardiness data in Fig. 12, will serve to emphasize that in no way could the hardiness achieved in the isolated or excised tissues be ascribed to increase in soluble sugars.

The hardiness, protein and nucleic acid data in Table 2 are typical of the data presented in Figs. 9, 10 and 11 for the results of encircling experiments performed in August on another tree. Data which have been added in Table 2 concern the soluble sugars, protein synthetic capacity and for later reference, phospholipides as well. The typical increase in hardiness from August to November in tissues encircled or excised in August and which occurred in the absence of the normal autumn increase in hardiness protein, RNA and protein synthetic capacity is clearly shown in Table 2. The signiffyant feature of these results is the greater hardiness achieved in the encircled tissue relative to the tissue excised and stored at $-5^{\circ} \mathrm{C}$ in spite of the greater depletion of the soluble sugars in the encircled tissue. This increased depletion was doubtless due to the exposure of the encircled tissues to the period of high temperatures in later summer. These results make it difficult to find a role for increase in soluble sugars in 
hardening.

\section{A Possible New Chemical Parameter of Hardiness}

It is obvious that a chemical mechanism affected by what appears to be sub-zero temperatures and different from anything that we had hitherto encountered is operating in the process of hardening which occurred in isolated tissues in the absence of protoplasmic augmentation. The elucidation of the nature of this process which we term the second hardening reaction is vital to the understanding of the hardiness problem especially if it provides a chemical parameter of the extent of the sub-zero effect. Some recent studies emanating from early observations have given indications of a chemical change which might yet provide a clue to the nature of this mechanism. In earlier studies (Siminovitch, 1948) it had been noted that more phospholipides could be extracted from air dried winter tissue than from summer tissue. It had been thought, although there is less certainty on this point now, that the extractability was related to some particular property manifested upon drying of the tissue. The more recent extractions still yield a greater amount of phospholipide in winter tissues but it is not certain how much effect the drying has on the yield. The most significant feature of these results is, however, the increased yield of phospholipids which can also be obtained from starved encircled tissue which has already undergone the hardening reaction without protoplasmic augmentation (Table 2). Even greater differences had been obtained earlier between normal and girdled tissues in November or December with different and inadequate methods. The data in Table 2 therefore provide for the first time a distinct suggestion of the existence of a chemical change related to the hardening in restricted tissues. It is too early to state that this property really reflects the chemical parameter of the second hardening reaction. Further studies on restricted tissues should help resolve this question.

\section{Acknowledgments}

The careful editing and critical appraisal of the manuscript by Dr. C. Frankton is gratefully acknowledged.

\section{References}

ASAHINA, É. 1962 Some notes on the mechanism of frost resistance in living animal and plant at climatic low temperatures. Bull. Marine Biol. St., Asamushi, 10, 251-256.

COMBEs, R. 1925 Migration des substances azotées des feilles vers les tiges au cours du jaunissement automnal. Compt. Rend. Acad. Sci., 180, 2056-2058.

Dexter, S. T., TotTingham, W. E., and Graber, L. E. 1932 Investigations of the hardiness of plants by measurement of electrical conductivity. Plant Physiol, 7, 63-78.

GiBBS, R. D. 1940 Studies on tree physiology II. Seasonal changes in the food reserves of field birch (Betula populifolia MARsh.) Can. J. Res., C 18, 1-19.

Heber, U. 1956 a Ursachen der Frostresistenz bei Winterweizen III. Die Bedeutung von Proteinen für die Frost Resistenz. Planta, 54, 34-67.

HEBER, U. 1959 b Beziehungen zwischen der Grösse von Chloroplasten und ihrem Gehalt an löslichen 
Eiweissen und Zuckern in Zusammenhang mit dem Frostresistenzproblem. Protoplasma, 51, 284-298.

KISSANE, J. M. and RoBINS, B. 1958 The fluorimetric measurement of desoxyribonucleic acid in animal tissues with special reference to the cerebral neavous system. J. Biol. Chem., 233, 184-188.

KOHN, H. and LEVITT, J. 1965 Frost hardiness studies on cabbage grown under controlled conditions. Plant Physiol., 40, 476-480.

KRamer, P. J. and Kozlowski, T. T. 1960 Physiology of Trees. McGraw Hill Book Co., Inc.

LevitT, J. 1936. Frost Hardening studies with living cells. II. Permeability in relation to frost resistance and the seasonal cycle. Can. J. Res., C 14, 285-305.

LevitT, J. 1956 The Hardiness of Plants. Academic Press, Inc., New York, 278 pp.

LEvitT, J. 1957 The role of cell sap concentration in frost hardiness. Plant Physiol., 32, $237-239$.

LEVITT, J. 1959 Effeets of artificial increase in sugar content on frost hardiness. Plant Physiol., 34, 401-404.

LEVITT, J. 1962 A sulfhydryl-disulfide hypothesis of frost injury and resistance in plants. $J$. Theoret. Biol., 3, 355-391.

LEVITT, J. and HASMAN, M. 1964 Mechanism of protection by non-penetrating and non-toxic solutes against freezing injury to plant Cells. Plant Physiol., 39, 409-412.

Lowry, O. H., Rosebrough, N. J., FARR, A. L., and RANDALL, R. J. 1951 Protein measurement with the folin phenol reagent. J. Biol. Chem., 193, 265-275.

ModlibowsKA, I., and Rogers, W. S. 1955 Freezing of plant tissues under the microscope. J. Exp. Botany, 6, 384-391.

MOORE, S. and STEIN, W. H. 1954 A modified ninhydrin reagent for the photometric determination of amino acids and related compounds. J. Biol. Chem., 211, 907-913.

OGUR, M. and Rosen, G. 1950 The nucleic acids of plant tissues. I. The extraction and estimation of deoxypentose nucleic acid and pentose nucleic acid. Arch. Biochem., 25, 262-276.

PARKER, J. 1959 Seasonal changes in white pine leaves : a comparison of cold resistance and freesugar fluctuations. Bot. Gaz., 121, 46-50.

SAKAI, A. 1962 a Mechanism of the protective action of sugars against frost injury in plant cells. Nature, 193, 89-90.

SAKAI, A. $1962 \mathrm{~b}$ Studies on the frost-hardiness of woody plants. I. The causal relation between sugar content and frost-hardiness. Low Temp. Sci., B 20, 1-40. (In Japanese with English summary).

SAKAI, A. 1963 Relation of internal and external factors on the increase of frost hardiness in woody plants. Abstract of the International Symposium on Cytoecology. Leningrad, Academy of Sciences of the U.S.S.R. Press, Moscow.

SAKAI, A. 1966 Studies of frost hardiness in woody plants. II. Effect of temperature on hardening. Plant Physiol., 41, 353-359.

Schmidt, G. and Thannhauser, S. J. 1945 A method for the determination' of desoxyribonucleic acid, ribonucleic acid and phosphoproteins in animal tissue. J. Biol. Chem., 161, 83-89.

SImINOVITCH, D: and SCARTH, G. W. 1938 A studies of the meahanism of frost injury to plants. Can. J. Res., C 16, 467-481.

Siminovitch, D. and LevitT, J. 1941 The relation between frost resistance and the physical state of protoplasm. II. The protoplasmic surface. Can. J. Res., C 19, 9-20.

Siminovitch, D. 1948 Seasonal chemical changes in the living bark of the common locust tree in relation to the problem of frost hardiness. Ph. D. Thesis, University of Minnesota, 1-54.

Siminovitch, D. and BRIGGS, D. R. 1949 The chemistry of the living bark of the black locust tree in relation to its frost hardiness. I. Seasonal variations in protein content. Arch. Biochem., 23, 8-17. 
Siminovitch, D. and BRIGGS, D. R. 1953 a The validity of plasmolysis and desiccation tests for determining the frost hardiness of bark tissue. Plant Physiol.; 28, 15-34.

Siminovitch, D. and BRIGGS, D. R. $1953 \mathrm{~b}$ Studies in the chemistry of the living bark of the black locust in relation to its frost hardiness. IV. Effects of ringing on translocation, protein synthesis and the development of hardiness. Plant Physiol., 28, 177-200.

Siminovitch, D., WiLson, C. M. and BRIGGS, D. R. 1953 Studies on the chemistry of the living bark of the black locust in relation to frost hardiness. V. Seasonal transformations and variations in the carbohydrates: starch-sucrose interconversions. Plant Physiol., 28, 383400.

Siminovitch, D. and BRIGGS, D. R. 1954 Studies on the chemistry of the living bark of the black locust in relation to its frost hardiness. VII. A possible direct effect of starch on the susceptibility of plants to freezing injury. Plant Physiol., 29, 331-332.

Siminovitch, D. and Chater, A. P. J. 1958 Biochemical processes in the living of the black locust tree in relation to frost hardiness and the seasonal cycle. In The Physiology of Forest Trees (K. V. Thimann, ed.), The Ronald Press Co., New York.

Siminovitch, D. 1963 Evidence from increase in ribonucleic acid and protein synthesis in autumn for increase in protoplasm during the frost-hardening of black locust bark cells. Can. J. Bot., 41, 1301-1308.

Siminovitch, D., Therrien, H., Gfeller, G. and Rheaume, B. 1964 The quantitative estimation of frost injury and resistance in black locust, alfalfa, and wheat tissues by determination of amino acids and other ninhydrin-reacting substances released after thawing. Can. J. Bot., 42, 637-649.

Siminovitch, D., Rheaume, B. and SAchar, R. 1967 Seasonal rhythmic increase in protoplasm and metabolic capacity adaptation of tree cells to freezing. A.A.A.S. Symposium Volume, Molecular Mechanisms of Temperature Adaptation (C. L. Prosser, ed.), WAShington, D. C., In press.

TUMANOV, I. I. 1963 Frost hardening of plants. Abstract of the International Symposium on Cytoecology. Leningrad, Academy of Sciences of the U.S.S.R. Press, Moscow. 